\title{
One-Pot Multicomponent Synthesis of Thiourea Derivatives in Cyclotriphosphazenes Moieties
}

\author{
Zainab Ngaini, ${ }^{1}$ Wan Sharifatun Handayani Wan Zulkiplee, ${ }^{2}$ \\ and Ainaa Nadiah Abd Halim ${ }^{1}$ \\ ${ }^{1}$ Faculty of Resource Science and Technology, Universiti Malaysia Sarawak, 94300 Kota Samarahan, Sarawak, Malaysia \\ ${ }^{2}$ Centre for Pre-University Studies, Universiti Malaysia Sarawak, 94300 Kota Samarahan, Sarawak, Malaysia \\ Correspondence should be addressed to Zainab Ngaini; nzainab@unimas.my
}

Received 15 March 2017; Revised 21 April 2017; Accepted 23 April 2017; Published 3 July 2017

Academic Editor: Liviu Mitu

Copyright (C) 2017 Zainab Ngaini et al. This is an open access article distributed under the Creative Commons Attribution License, which permits unrestricted use, distribution, and reproduction in any medium, provided the original work is properly cited.

\begin{abstract}
In this study, hexasubstituted thiourea was carried out via reaction of isothiocyanato cyclophosphazene intermediates with a series of aromatics amines and amino acids in a one-pot reaction system. The reaction was not as straightforward as typical thiourea synthesis. Six unexpected thiourea derivatives $\mathbf{3 a}-\mathbf{f}$ were formed in the presence of cyclotriphosphazene moieties in good yields (53-82\%). The structures of $\mathbf{3 a}-\mathbf{f}$ were characterized by elemental analysis and FTIR, ${ }^{1} \mathrm{H}$, ${ }^{13} \mathrm{C}$, and ${ }^{31} \mathrm{P}$ NMR spectroscopies. The occurrence of reverse thioureas formation in a one-pot reaction system is discussed. The possible binding interaction of the synthesised thiourea $\mathbf{3} \mathbf{a}-\mathbf{b}$ in comparison to the predicted phenyl thiourea $\mathbf{5 a}-\mathbf{b}$ and the targeted $\mathbf{4 a}$ with enzyme enoyl ACP reductase (FabI) is also discussed. Molecular docking of the targeted hexasubstituted thiourea $4 \mathbf{a}$ is able to give higher binding affinity of $-7.5 \mathrm{kcal} / \mathrm{mol}$ compared to $5 \mathbf{a}-\mathbf{b}(-5.9 \mathrm{kcal} / \mathrm{mol}$ and $-6.3 \mathrm{kcal} / \mathrm{mol})$ and thiourea $3 \mathbf{a}-\mathbf{b}(-4.5 \mathrm{kcal} / \mathrm{mol}$ and $-4.7 \mathrm{Kcal} / \mathrm{mol})$.
\end{abstract}

\section{Introduction}

Thiourea is widely studied and claimed to be used in many applications such as herbicides, pharmaceutical agents, pesticides, rodenticides, vulcanization accelerator, and scaffolds in organic synthesis [1]. In the synthesis of thiourea, isothiocyanate is formed as a reactive intermediate and easily converted to other side product during isolation [2]. Many studies reported on the direct reaction of isothiocyanate intermediate with amines after isolation of $\mathrm{KCl}$ to produce thiourea in good purity [3].

Several studies reported on monosubstituted thiourea which consists of one thiourea moiety either as a ligand bearing aromatic, halogen, or alkyl substituents [4] or as a complex compound coordinated with heavy metal center [5]. Multisubstituted thioureas have gained more interest among researchers due to the increase of their pharmaceutical properties. Our recent studies on thiourea reported that compounds that consist of more than one thiourea moiety possess better antimicrobial activities [6-8]. It was due to the presence of more active sites of thiourea moieties containing $\mathrm{C}=\mathrm{S}, \mathrm{C}=\mathrm{O}$, and $\mathrm{N}-\mathrm{H}$ groups, which are easily protonated under acidic condition and interacted with the carboxyl and phosphate groups of the bacterial surfaces, thus enhancing the biological activities [7]. Various methods have been reported to make this versatile group of thiourea derivatives easily accessible with excellent yields [2, 9-12].

Hexakisphosphazenes bearing thioureas moieties have been reported from the stepwise reaction of the isolated isothiocyanate intermediates with a series of aliphatic amines via $\mathrm{P}-\mathrm{Cl}$ substitution of hexachlorocyclotriphosphazene [13]. Hexachlorocyclotriphosphazene, a cyclic inorganic compound with alternating phosphorus and nitrogen atoms, has sparked great interest among researchers for an excellent candidate in constructing hexasubstituted molecules $[14,15]$. The substitution of $\mathrm{P}-\mathrm{Cl}$ bonds with various types of nucleophiles allowed the construction of phosphazenes-based ligands with different types of physical and chemical properties [16]. A wide range of hexasubstituted phosphazene derivatives with 
various substituents such as hydroxyl, amino, and many other functional groups had been reported $[13,15,16]$.

To the best of our knowledge, no studies reported on the synthesis of hexasubstituted thiourea onto cyclotriphosphazene moieties bearing six units of amino acid or aromatic amines. Our previous studies reported on thiourea bearing aromatic amine with excellent antibacterial properties $[6,17]$. In continuation to our previous work, in this article, we report on the synthesis of thiourea compounds with hexachlorocyclotriphosphazene as a hexasubstituted precursor in a typical one-pot reaction system [11]. The plausible mechanism which leads to the unexpected final products is discussed. The binding interaction of the synthesised thiourea via molecular docking interaction in comparison to predicted phenyl thiourea and the targeted compound with enzyme enoyl ACP reductase $(\mathrm{FabI})$ is also thoroughly discussed.

\section{Materials and Methods}

Hexachlorocyclotriphosphazene (99\%) was purchased from Aldrich. Potassium thiocyanate, aniline, $\rho$-toluidine, $\rho-$ anisidine, glycine, L-alanine, and L-phenyl alanine were obtained from Merck and used without purification. Acetone was distilled over magnesium sulphate anhydrous. All other reagents and solvent were used as received.

Physical Measurement. Melting points were determined by the open tube capillary method and were uncorrected. Infrared spectra $\left(\nu / \mathrm{cm}^{-1}\right)$ were recorded as $\mathrm{KBr}$ pellets on a Perkin Elmer 1605 FTIR spectrophotometer. ${ }^{1} \mathrm{H}$ and ${ }^{13} \mathrm{C}$ NMR spectra were recorded on a JEOL ECA 500 spectrometer at $500 \mathrm{MHz}\left({ }^{1} \mathrm{H}\right)$ and $125 \mathrm{MHz}\left({ }^{13} \mathrm{C}\right)$, respectively, with the chemical shifts $\delta$ (ppm) being reported relative to DMSO$\mathrm{d}_{6}$ as standard. The chemical shifts for ${ }^{31} \mathrm{P}$ NMR are relative to the internal standard of $85 \%$ phosphoric acid. CHNS microanalyses were performed by use of a FLASHEA 1112 CHNS analyser.

2.1. General Procedure for the Synthesis of $\mathbf{3 a}-\boldsymbol{f}$. A mixture of hexachlorocyclotriphosphazene $(0.35 \mathrm{~g}, 1.0 \mathrm{mmol})$ in dry acetone $(15.0 \mathrm{~mL})$ was added dropwise into a solution of potassium thiocyanate $(0.87 \mathrm{~g}, 9.0 \mathrm{mmol})$ in dry acetone $(15.0 \mathrm{~mL})$. The mixture was stirred for $1 \mathrm{~h}$ at room temperature to form intermediate 2 . The white potassium chloride $(\mathrm{KCl})$ was filtered. The filtrate was added to amine $(6.0 \mathrm{mmol})$ in dry acetone $(15.0 \mathrm{~mL})$ and heated under reflux for $18 \mathrm{~h}$. The mixture was cooled to room temperature and filtered. The filtrate was evaporated in vacuum to form a yellowish powder. The crude was recrystallized in EtOH : $\mathrm{CH}_{3} \mathrm{CN}(1: 1)$. The general procedure for the preparation of $\mathbf{3 a}-\mathbf{f}$ utilised a different type of amines (g, mmol) and yields as follows.

Phenylthiourea (3a) [18]. Aniline (565.0 $\mu \mathrm{L}, 6 \mathrm{mmol})$. (73\% yield) as a white crystal, m.p: $153.2-153.5^{\circ} \mathrm{C}$ (lit [18] $\left.163^{\circ} \mathrm{C}\right)$.

p-Tolylthiourea (3b) [19]. p-Toluidine $(0.643 \mathrm{~g}, 6 \mathrm{mmol})$. (82\% yield) as a white crystal, m.p: $167.8-168.8^{\circ} \mathrm{C}$ (lit [19] $\left.182-186^{\circ} \mathrm{C}\right)$.
(4-Methoxyphenyl) Thiourea (3c) [18]. p-Anisidine (0.739g, $6 \mathrm{mmol}) .\left(68 \%\right.$ yield) as grey powder, m.p: $172.4-173.2^{\circ} \mathrm{C}$ (lit [18] $\left.193^{\circ} \mathrm{C}\right)$.

2-(Carbamothioylamino) Acetic Acid (3d) [20]. Glycine $(0.451 \mathrm{~g}, 6 \mathrm{mmol})$. (53\% yield) as a yellowish powder, m.p: $133.1-134.5^{\circ} \mathrm{C}$ (lit [20] $\left.176-179^{\circ} \mathrm{C}\right)$.

2-(Carbamothioylamino) Propanoic Acid (3e). L-alanine $(0.534 \mathrm{~g}, 6 \mathrm{mmol})$. (62\% yield) as a yellow powder, m.p: $138.8-139.5^{\circ} \mathrm{C}$; $v_{\max }\left(\mathrm{KBr} / \mathrm{cm}^{-1}\right) 3229(\mathrm{OH}) 3010(\mathrm{NH}), 2968$ $(\mathrm{CH}), 1698(\mathrm{COOH}) 1226(\mathrm{C}=\mathrm{S}) . \delta_{\mathrm{H}}(500 \mathrm{MHz}, \mathrm{DMSO}-$ $\left.\mathrm{d}_{6}\right) 1.59\left(3 \mathrm{H}, \mathrm{d}, J=6.8, \mathrm{CH}_{3}\right), 5.10(1 \mathrm{H}, \mathrm{q}, \mathrm{CH}), 10.11(2 \mathrm{H}$, s, $\left.\mathrm{NH}_{2}\right), 10.54(1 \mathrm{H}, \mathrm{s}, \mathrm{NH}) . \delta_{\mathrm{C}}\left(125 \mathrm{MHz}, \mathrm{DMSO}-\mathrm{d}_{6}\right) 17.0$ $\left(\mathrm{CH}_{3}\right), 61.9(\mathrm{CH}), 173.5(\mathrm{COOH}), 180.6(\mathrm{C}=\mathrm{S})$. Calculated for $\mathrm{C}_{4} \mathrm{H}_{8} \mathrm{~N}_{2} \mathrm{O}_{2} \mathrm{~S}$ : C, 32.40; H, 5.40; N, 18.90; S, 21.60\%, found C, 31.74; H, 4.98; N, 18.79; S, 21.64\%.

2-(Carbamothioylamino)-3-phenyl-propanoic Acid (3f). Lphenyl alanine $(0.990 \mathrm{~g}, 6 \mathrm{mmol})$. (61\% yield) as a yellow crystal, m.p: $198.3-198.9^{\circ} \mathrm{C}$; $\nu_{\max }\left(\mathrm{KBr} / \mathrm{cm}^{-1}\right) 3172(\mathrm{OH}) 3100$ (NH), $2911(\mathrm{CH}), 1740(\mathrm{COOH}) 1452(\mathrm{Ar}-\mathrm{C}), 1249(\mathrm{C}=\mathrm{S}) . \delta_{\mathrm{H}}$ $\left(500 \mathrm{MHz}, \mathrm{DMSO}-\mathrm{d}_{6}\right) 3.89\left(2 \mathrm{H}, \mathrm{d}, J=13.8, \mathrm{CH}_{2}\right), 5.42(1 \mathrm{H}$, q, CH) $7.05(2 \mathrm{H}, \mathrm{d}, J=6.3, \mathrm{Ar}-\mathrm{H}), 7.28(3 \mathrm{H}, \mathrm{m}, \mathrm{Ar}-\mathrm{H}), 10.19$ $\left(2 \mathrm{H}, \mathrm{s}, \mathrm{NH}_{2}\right), 10.63(1 \mathrm{H}, \mathrm{s}, \mathrm{NH}) . \delta_{\mathrm{C}}\left(125 \mathrm{MHz}, \mathrm{DMSO}-\mathrm{d}_{6}\right)$ $35.9\left(\mathrm{CH}_{2}\right), 67.0(\mathrm{CH}), 127.8,128.9,129.8,134.5$ (Ar-C), 172.5 $(\mathrm{COOH}), 179.9(\mathrm{C}=\mathrm{S})$. Calculated for $\mathrm{C}_{10} \mathrm{H}_{12} \mathrm{~N}_{2} \mathrm{O}_{2} \mathrm{~S}$ : C, 53.60; H, 5.40; N, 12.50; S, 14.30\%, found: C, 53.35; H, 5.31; N, 12.17; S, $14.02 \%$.

2.2. Antibacterial Screening. Antibacterial activities of $\mathbf{3 a}-\mathbf{f}$ were analysed against E. coli (ATCC 8739) using the turbidimetric kinetic method. The Gram-negative E. coli were cultured on a Luria-Bertani plate agar at $37^{\circ} \mathrm{C}$. Then a colony of the inoculums was transferred and allowed to grow in media containing nutrient broth at $37^{\circ} \mathrm{C}$ with permanent stirring at $250 \mathrm{rpm}$ for overnight. $0.2 \mathrm{~mL}$ of inoculums was inoculated with $10 \mathrm{~mL}$ of culture medium that has been added with increasing concentration of synthesised compounds dissolved in DMSO. The mixture was shaken at $180 \mathrm{rpm}$ at $37^{\circ} \mathrm{C}$. The negative control was medium broth of inoculums with solvent. The aliquots of each replicate were taken on every $1 \mathrm{~h}$ interval for $6 \mathrm{~h}$. The transmittance $(T)$ was recorded using UV-Visible Spectrophotometer Optima SP-300. The antibacterial activity was determined by plotting a graph of $\ln N_{t}$ versus time. The $\ln N t$ value represents the number of colony forming units/mL which followed the expression of $\ln N_{t}=27.1-8.56 T$ [21].

2.3. Molecular Docking. Molecular docking studies on the series of $\mathbf{3 a - b}, \mathbf{4 a}$, and $\mathbf{5} \mathbf{a}-\mathbf{b}$ were carried out using AutoDock Vina 1.1.2 program [22]. The polar hydrogens of the synthesised compounds and protein were added with AutoDock Tools 1.5.6 [23] before docking using Auto-Dock Vina program. In Auto-Dock Vina program, the cubic grid box of $60^{\circ} \mathrm{A}$ sizes $\left(x, y\right.$, and $z$ ) with a spacing of $0.375^{\circ} \mathrm{A}$ was centered to the active site of the protein. The X-ray crystal structure of the enzyme enoyl ACP reductase (FabI) of $E$. 
<smiles>ClP1(Cl)=NP(Cl)(Cl)=NP(Cl)(Cl)=N1</smiles>

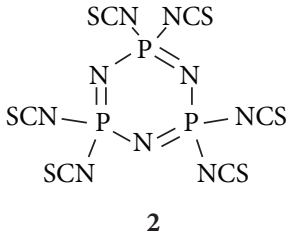<smiles>CC[Y4]([14CH3])([14CH3])N</smiles>

NHCSNHR ${ }^{\prime}$ NHCSNHR

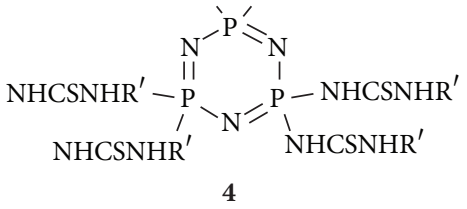

SCHEME 1: The synthesis of $\mathbf{3 a}-\mathbf{f}$.

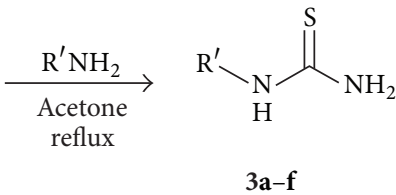

$\mathrm{R}^{\prime} \mathbf{a}=\mathrm{C}_{6} \mathrm{H}_{5}$ $\mathbf{b}=\mathrm{C}_{6} \mathrm{H}_{5} \mathrm{CH}_{3}$ c $=\mathrm{C}_{6} \mathrm{H}_{5} \mathrm{OCH}_{3}$ $\mathbf{d}=\mathrm{CH}_{2}(\mathrm{COOH})$ $\mathbf{e}=\left(\mathrm{CH}_{3}\right) \mathrm{CH}(\mathrm{COOH})$ $\mathbf{f}=\left(\mathrm{C}_{6} \mathrm{H}_{5}\right) \mathrm{CH}_{2} \mathrm{CH}(\mathrm{COOH})$ coli (PDB entry: 1C14) was obtained from Protein Data Bank (http://www.rcsb.org/pdb/home/home.do) [7, 24].

\section{Results and Discussion}

3.1. Chemistry. The synthesis of the proposed hexasubstituted thioureas $4 \mathbf{a}-\mathbf{f}$ was prepared via reaction of hexachlorocyclotriphosphazene with potassium thiocyanate to form isothiocyanates phosphazene intermediates, followed by typical thiourea reaction with a series of amines derivatives in a one-pot reaction system. All compounds were subjected to IR spectroscopy and showed the disappearance of $v$ (NCS) at $2140-1990 \mathrm{~cm}^{-1}$ and the formation of $v(\mathrm{~N}-\mathrm{H})$ at $3276-3010 \mathrm{~cm}^{-1}$. The formation of thiourea was evidenced by the strong absorption peak at $1265-1227 \mathrm{~cm}^{-1}$ corresponding to $v(\mathrm{C}=\mathrm{S})$ which shifted to the lower frequency due to the attachment of more electronegative nitrogen atoms [25]. The absorbance peak attributed to the formation of $v(\mathrm{P}=\mathrm{N})$ asymmetric vibration at $1400-1200 \mathrm{~cm}^{-1}[26,27]$ but, however, was not observed. This phenomenon was also transpired in ${ }^{31} \mathrm{P}$ NMR spectra where no phosphorus moieties were present.

Further characterization of the synthesised compounds via ${ }^{1} \mathrm{H}$ NMR showed the presence of thiourea (-NHCSNH-) represented by two NH peaks at $9.80-9.30 \mathrm{ppm}$ and $3.33-$ $3.30 \mathrm{ppm}$. The higher resonance of $\mathrm{NH}$ peaks in $\mathbf{3 d}-\mathbf{f}$ at $10.84-10.53 \mathrm{ppm}$ and $10.18-10.01 \mathrm{ppm}$ was due to downfield effect resulting from the formation of intramolecular hydrogen bond between the hydrogen atom from thiourea moieties with oxygen atom from the carboxylic acid group [5]. ${ }^{13} \mathrm{C}$ NMR spectra of compound $\mathbf{3 a}-\mathbf{f}$ showed good agreement with the corresponded structures with the presence of $\mathrm{C}=\mathrm{S}$ peak at $181.2-180.9 \mathrm{ppm}$ [28-30].

Elemental analysis of the synthesised compounds afforded low carbon percentage in each compound which indicated the formation of $\mathbf{3 a}-\mathbf{f}$. Based on the IR, ${ }^{1} \mathrm{H},{ }^{13} \mathrm{C}$, and ${ }^{31} \mathrm{P}$ NMR spectra, it was suggested that $\mathbf{3 a}-\mathbf{f}$ were synthesised in one-pot reaction system and not the targeted molecule 4a-f (Scheme 1).

The presence of hexachlorocyclotriphosphazene in a one-pot reaction system is envisaged, not only forming isothiocyanate intermediate 2 via $\mathrm{P}-\mathrm{Cl}$ substitution but also generating $\mathrm{Cl}^{-}$from the partially soluble $\mathrm{KCl}$ in acetone [31]. The free chlorine ions deprotonate amines in the reaction system and form $\mathrm{HCl}$ and anionic amines, which in turn reacted with hydrogen thiocyanate [18] and formed $\mathbf{3 a}-\mathbf{f}$. The plausible mechanism for the formation of $\mathbf{3} \mathbf{a}-\mathbf{f}$ is shown in Scheme 2.

3.2. Antibacterial Activity. Compounds $3 \mathbf{a}-\mathbf{f}$ were further investigated for antibacterial activities by plotting the graph of $\ln N_{t}$ versus time. Compounds $\mathbf{3 a}-\mathbf{f}$ were examined at the concentration of $50 \mathrm{ppm}, 80 \mathrm{ppm}$, and $100 \mathrm{ppm}$ against wildtype $E$ coli at $37^{\circ} \mathrm{C}$. The result indicated that compounds $\mathbf{3 a}-\mathbf{f}$ showed poor inhibition against E. coli. The MIC graph for compounds $3 \mathbf{a}-\mathbf{f}$ as shown in Figure 1 was determined by extrapolating the concentration at the zero-growth rate of $E$. coli $(\mu=0)$ [32]. The MIC values for all compounds $3 \mathbf{a}-\mathbf{f}$ were observed to exceed $220 \mathrm{ppm}$. Compounds with MIC value up to $400 \mathrm{ppm}$ are considered to have inhibition activity against growth of Gram-negative bacteria, but only compounds with MIC value smaller than $220 \mathrm{ppm}$ can be suggested for clinical purposes [33].

Like other typical Gram-negative bacteria, the cell wall of $E$. coli is made up from thin layer of peptidoglycan and an outer membrane constituted of lipopolysaccharide, lipoprotein, and phospholipids [34]. In view of this, the large molecular weight compound is required to coat the cell surface and prevent the leakage of intercellular components of the bacteria [32].

3.3. Molecular Docking Design and Optimisation. For a better understanding of the interaction between thiourea derivatives and Gram-negative bacteria E. coli, molecular docking 

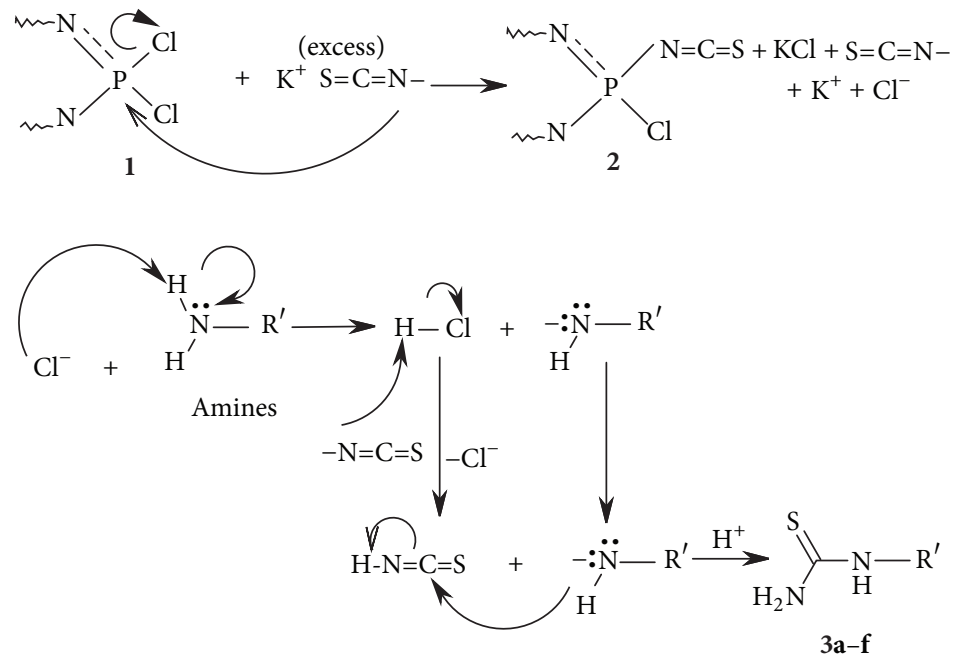

Scheme 2: Mechanism on the formation of $\mathbf{3 a}-\mathbf{f}$.

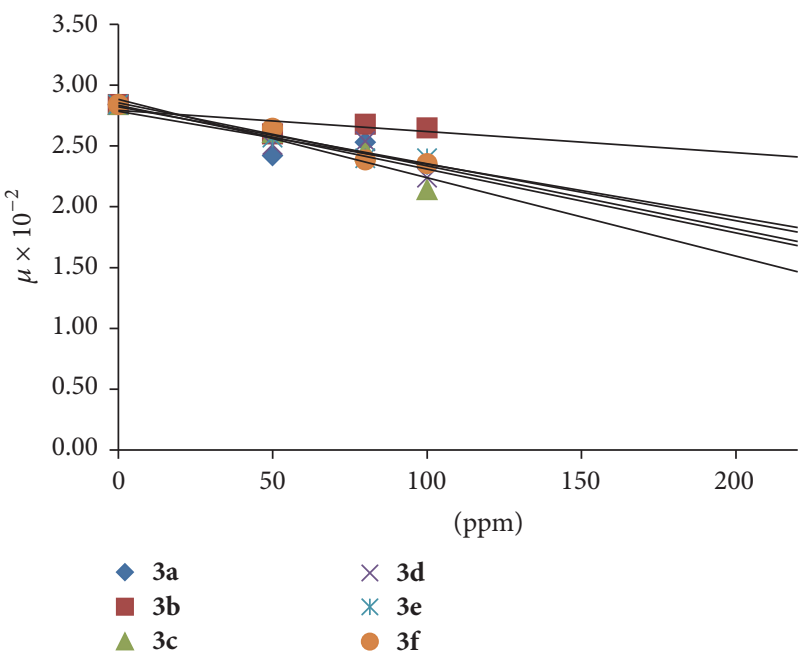

FIGURE 1: MIC graph for 3a-f.

studies were carried out and optimised by comparing $\mathbf{3 a - b}$ with the predicted phenyl thiourea $\mathbf{5 a - b}$ and the targeted $\mathbf{4 a}$. The studies were carried out via molecular docking to the active site of the enzyme enoyl ACP reductase (FabI) of E. coli (PDB entry: 1C14) using AutoDock Vina 1.1.2 program [7, 2224]. The compounds and binding interactions are shown in Table 1 . The binding affinity of the compounds was evaluated based on binding free energies $(\Delta G b, \mathrm{kcal} / \mathrm{mol})$ [35].

The binding model of thiourea and the predicted phenyl thiourea $\mathbf{5 a}-\mathbf{b}$ is depicted in Table 1 . Compounds $\mathbf{3} \mathbf{a}-\mathbf{b}$ showed binding free energy of $-4.5 \mathrm{kcal} / \mathrm{mol}$ and $-4.7 \mathrm{kcal} / \mathrm{mol}$, respectively. Based on the importance properties of the aromatic group in earlier studies [6-8], the optimisation study via molecular docking was carried out to evaluate the binding free energy of $\mathbf{3 a}-\mathbf{b}$ in comparison to the predicted phenyl thiourea $\mathbf{5 a}-\mathbf{b}$. The presence of another aromatic group in 5a-b demonstrated for a higher binding affinity with the free energy of $-5.9 \mathrm{kcal} / \mathrm{mol}$ and $-6.3 \mathrm{kcal} / \mathrm{mol}$, respectively. The additional aromatic group in $\mathbf{5 a}-\mathbf{b}$ is strongly bound to enzyme enoyl ACP reductase (FabI) of E. coli through $\pi$ $\pi$ bond interactions (yellow colour cylindrical wireframe) with hydrophobic pockets of Phe 1251. The hydrophobic interaction between phenyl rings has increased the lipophilicity of the compound $[7,33]$. The binding affinity of $\mathbf{5 b}$ is slightly higher than $\mathbf{5 a}$ due to the electron donating inductive effect of the substituted methyl group, which provides better interactions network with the active site residues [36]. The absence of aromatic ring was accountable for lesser binding affinity resulting in less activity in $\mathbf{3 a - b}$ [37].

Due to the importance of phenyl groups for a better binding affinity, it is noteworthy to analyse the significance of hexasubstituted thiourea moieties onto cyclotriphosphazene 4a. Based on Table 1, the presence of six thiourea moieties in $4 \mathbf{a}$ showed the highest binding affinity with a free energy of $-7.5 \mathrm{kcal} / \mathrm{mol}$. Apart from the $\pi-\pi$ bond interactions with Phe 1251, 4a was observed to interact with the enzyme via two hydrogen bonds (green colour sphere). The NH groups in 4a are forming hydrogen bonding with $\mathrm{C}=\mathrm{O}$ and $\mathrm{NH}$ of Ala 1152 . The bonding provides specificity and stabilisation of binding between $4 \mathbf{a}$ and enzyme active site which consequently enhanced the binding affinity $[38,39]$. Other basic residues such as Pro 1154, Ile 1153, Val 1213, Ala 1254, Hoh 2087, Hoh 2067, Arg 171, and Gly 242 were observed in the vicinity of compound $\mathbf{4 a}$, which suggested that a strong electrostatic interaction was also involved in the binding process [40].

\section{Conclusions}

In summary, the thiourea derivatives $\mathbf{3 a}-\mathbf{f}$ were unexpectedly synthesised from the reaction of amines with excess thiocyanates groups in a one-pot reaction system. The isolation of isothiocyanato cyclophosphazene intermediates could be the best method to give hexasubstituted thioureas. The formation of $\mathrm{HCl}$ in the reaction condition was envisaged to be responsible for the deprotonation of amines, thus reducing the 
TABLE 1: Molecular docking images of thiourea derivatives.

Compound Docking image

$5 a$<smiles>S=C(Nc1ccccc1)Nc1ccccc1</smiles>

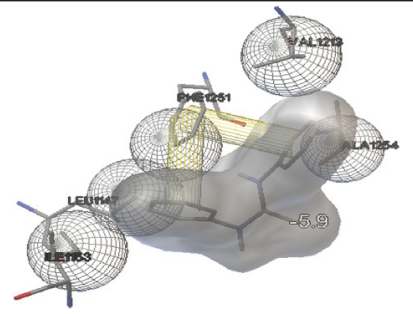

$5 b$<smiles>Cc1ccc(NC(=S)Nc2ccccc2)cc1</smiles>

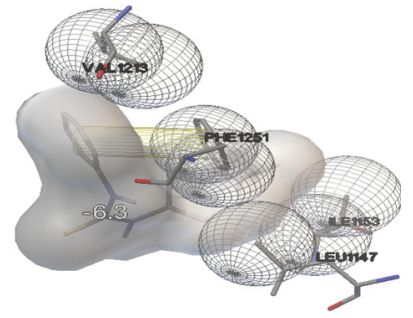

4
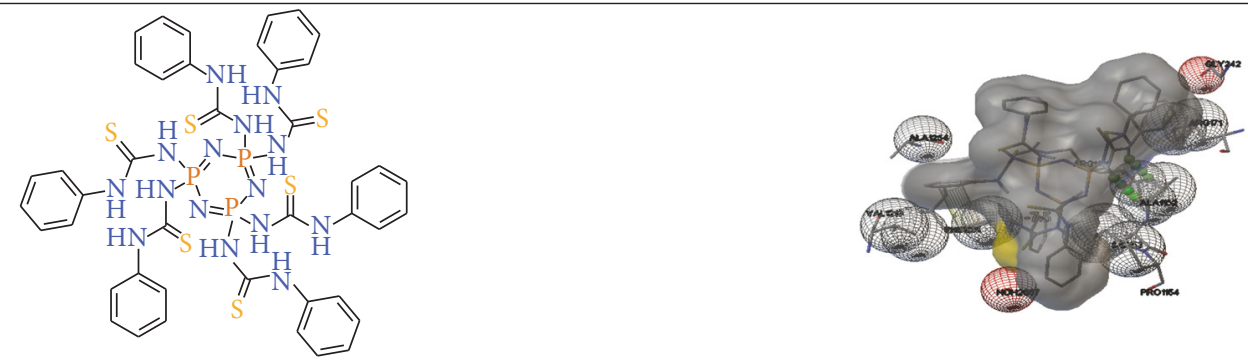

possible formation of hexasubstituted thioureas. Biological activities of thiourea $\mathbf{3 a - f}$ showed poor inhibitions towards E. coli. Molecular docking interaction study thoroughly explained the binding interactions of the selected thiourea 3ab compared to the binding affinity with the predicted $\mathbf{5 a - b}$ and the targeted 4a. Based on the molecular docking study, it can be concluded that the targeted hexasubstituted thiourea as in $\mathbf{4 a}$ is envisaged to give better binding affinity compared to monothiourea $\mathbf{3 a}-\mathbf{f}$.

\section{Conflicts of Interest}

The authors declare that there are no conflicts of interest regarding the publication of this paper.

\section{Acknowledgments}

The authors would like to acknowledge Universiti Malaysia Sarawak and the Ministry of Higher Education for financial support through C09/SpSTG/1359/16/1 and FRGS/ST01(01)/1298/2015(15). They acknowledge Universiti Malaysia Terengganu, Malaysia, for providing CHNS elemental analysis services.

\section{References}

[1] P. K. Mohanta, S. Dhar, S. K. Samal, H. Ila, and H. Junjappa, "1(Methyldithiocarbonyl)imidazole: A useful thiocarbonyl transfer reagent for synthesis of substituted thioureas," Tetrahedron, vol. 56, no. 4, pp. 629-637, 2000. 
[2] N. Sun, B. Li, J. Shao et al., "A general and facile one-pot process of isothiocyanates from amines under aqueous conditions," Beilstein Journal of Organic Chemistry, vol. 8, pp. 61-70, 2012.

[3] A. Saeed, N. Abbas, H. Rafique, S. Rashid, and A. Hameed, "Synthesis, characterization and antibacterial activity of some 1-aroyl-3-aryl thiourea," Chemistry, vol. 18, no. 5, pp. 152-158, 2009.

[4] N. A. Nordin, T. W. Chai, B. L. Tan et al., "Novel synthetic monothiourea aspirin derivatives bearing alkylated amines as potential antimicrobial agents," Journal of Chemistry, vol. 2017, no. 1, pp. 1-7, 2017.

[5] M. K. Rauf, Imtiaz-ud-Din, A. Badshah et al., "Synthesis, structural characterization and in vitro cytotoxicity and antibacterial activity of some copper (I) complexes with N, N/disubstituted thioureas," Journal of Inorganic Biochemistry, vol. 103, no. 8, pp. 1135-1144, 2009.

[6] W. S. H. Wan Zullkiplee, A. N. Abd Halim, Z. Ngaini, M. A. Mohd Ariff, and H. Hussain, "Bis-Thiourea bearing aryl and amino acids side chains and their antibacterial activities," Phosphorus, Sulfur and Silicon and the Related Elements, vol. 189, no. 6, pp. 832-838, 2014.

[7] A. N. Abd Halim and Z. Ngaini, "Synthesis and bacteriostatic activities of bis (thiourea) derivatives with variable chain length," Journal of Chemistry, vol. 2016, no. 1, pp. 1-7, 2016.

[8] W. S. H. Wan Zullkiplee, M. A. Mohd Ariff, H. Hussain, W. M. Khairul, and Z. Ngaini, "Bacteriostatic activities of $\mathrm{N}$-substituted tris-thioureas bearing amino acid and aniline substituents," Phosphorus, Sulfur and Silicon and the Related Elements, pp. 1-5, 2016.

[9] W. Fathalla, M. Čajan, J. Marek, and P. Pazdera, "One-pot quinazolin-4-yl-thiourea synthesis via $N$-(2-cyanophenyl)benzimidoyl isothiocyanate," Molecules, vol. 6, no. 7, pp. 588-602, 2001.

[10] N. Azizi, A. Khajeh-Amiri, H. Ghafuri, and M. Bolourtchian, "Toward a practical and waste-free synthesis of thioureas in water," Molecular Diversity, vol. 15, no. 1, pp. 157-161, 2011.

[11] K. Appalanaidu, T. Dadmal, N. Jagadeesh Babu, and R. M. Kumbhare, "An improved one-pot multicomponent strategy for the preparation of thiazoline, thiazolidinone and thiazolidinol scaffolds," RSC Advances, vol. 5, no. 107, pp. 88063-88069, 2015.

[12] V. Štrukil, M. D. Igrc, L. Fábián et al., "A model for a solvent-free synthetic organic research laboratory: Click-mechanosynthesis and structural characterization of thioureas without bulk solvents," Green Chemistry, vol. 14, no. 9, pp. 2462-2473, 2012.

[13] H. R. Allcock, J. S. Rutt, and M. Parvez, "Synthesis of cyclic phosphazenes with isothiocyanato, thiourethane, and thiourea side groups: X-ray crystal structure of N3P3(NMe2)3(NCS)3," Inorganic Chemistry, vol. 30, no. 1, pp. 1776-1782, 1991.

[14] Z. Ngaini and N. I. A. Rahman, "Synthesis and characterization of chalconesubstituted phosphazenes," Canadian Journal of Chemistry, vol. 88, no. 7, pp. 654-658, 2010.

[15] Z. Ngaini and N. I. A. Rahman, "Synthesis and characterization of cyclotriphosphazenes bearing chalcones derivatives," Phosphorus, Sulfur and Silicon and the Related Elements, vol. 185, no. 3, pp. 628-633, 2010.

[16] R. K. Voznicová, J. Taraba, J. Př́hoda, and M. Alberti, “The synthesis and characterization of new aminoadamantane derivatives of hexachloro-cyclo-triphosphazene," Polyhedron, vol. 27, no. 9-10, pp. 2077-2082, 2008.

[17] Z. Ngaini, M. A. Mohd Arif, H. Hussain, E. S. Mei, D. Tang, and D. H. A. Kamaluddin, "Synthesis and antibacterial activity of acetoxybenzoyl thioureas with aryl and amino acid side Chains," Phosphorus, Sulfur and Silicon and the Related Elements, vol. 187, no. 1, pp. 1-7, 2012.

[18] P. Venkatesh and S. N. Pandeya, "Synthesis, characterisation and anti-inflammatory activity of some 2 -amino benzothiazole derivatives," International Journal of ChemTech Research, vol. 1, no. 4, pp. 1354-1358, 2009.

[19] R. L. Smith and R. T. Williams, "The metabolism of arylthioureas - IV. p-chorophenyl- and p-tolyl-thiourea," Journal of Medicinal and Pharmaceutical Chemistry, vol. 4, no. 1, pp. 147162, 1961.

[20] National Center for Biotechnology Information, PubChem Compound Database, Apr 2017, CID = 3040094, https://pubchem .ncbi.nlm.nih.gov/compound/3040094.

[21] N. B. Pappano, O. P. Centorbi, and F. H. Ferretti, "Determination of minimum concentration inhibitory chalcone derivatives," Revise Microbiology, vol. 2, no. 1, pp. 183-188, 1990.

[22] O. Trott and A. J. Olson, "AutoDock Vina: improving the speed and accuracy of docking with a new scoring function, efficient optimization and multithreading," Journal of Computational Chemistry, vol. 31, no. 2, pp. 455-461, 2010.

[23] G. M. Morris, H. Ruth, W. Lindstrom et al., "Software news and updates AutoDock4 and AutoDockTools4: automated docking with selective receptor flexibility," Journal of Computational Chemistry, vol. 30, no. 16, pp. 2785-2791, 2009.

[24] S. George, M. B. Ramzeena, S. V. Ram, S. K. Selvaraj, S. Rajan, and T. K. Ravi, "Design, docking, synthesis and anti E. coli screening of novel thiadiazolo thiourea derivatives as possible inhibitors of enoyl ACP reductase (FabI) enzyme," Bangladesh Journal of Pharmacology, vol. 9, no. 1, pp. 49-53, 2014.

[25] Y. K. Shao and J. X. Si, "Synthesis and herbicidal activity of $\mathrm{N}$-(o-flourophenoxyacetyl) thiourea activities and related fused heterocyclic compound," Arkivoc, vol. 10, pp. 63-68, 2006.

[26] K. Moriya, T. Masuda, T. Suzuki, S. Yano, and M. Kajiwara, "Liquid crystalline phase transition in hexakis (4-(n-(41alkoxyphenyl) iminomethyl) phenoxy) cyclotriphosphazene," Molecular Crystals and Liquid Crystals, vol. 318, no. 1, pp. 267278, 1998.

[27] E. Cil, M. Arslan, and A. O. Gorgulu, "Synthesis and characterisationof benzyl andbenzoyl substituted oxime-phosphazees," Polyhedron, vol. 25, no. 18, pp. 3526-3532, 2006.

[28] G. G. Muccioli, J. Wouters, G. K. E. Scriba, W. Poppitz, J. H. Poupaert, and D. M. Lambert, "1-Benzhydryl-3-phenylurea and 1-benzhydryl-3-phenylthiourea derivatives: New templates among the CB1 cannabinoid receptor inverse agonists," Journal of Medicinal Chemistry, vol. 48, no. 23, pp. 7486-7490, 2005.

[29] Y.-H. Shen and D.-J. Xu, "Phenylthiourea," Acta Crystallographica Section E: Structure Reports Online, vol. 60, no. 7, pp. ol193ol194, 2004.

[30] R. S. Corrêa, O. Estévez-Hernández, J. Ellena, and J. Duque, "1(2-Furoyl)-3-(o-tolyl)thiourea," Acta Crystallographica Section E: Structure Reports Online, vol. 64, no. 8, p. o1414, 2008.

[31] H. R. Allcock, Phosphorus-Nitrogen Compounds: Cyclic, Linear, and High Polymeric Systems, Academic Press, Elsevier, New York, NY, USA, 1972.

[32] M. De Los Angeles Alvarez, V. E. P. Zarelli, N. B. Pappano, and N. B. Debattista, "Bacteriostatic action of synthetic polyhydroxylated chalcones against Escherichia coli," Biocell, vol. 28, no. 1, pp. 31-34, 2004.

[33] H. Arslan, N. Duran, G. Borekci, C. K. Ozer, and C. Akbay, "Antimicrobial activity of some thiourea derivatives and their 
nickel and copper complexes," Molecules, vol. 14, no. 1, pp. 519527, 2009.

[34] J. L. Ramos, S. Marqués, and K. N. Timmis, "Transcriptional control of the Pseudomonas TOL plasmid catabolic operons is achieved through an interplay of host factors and plasmidencoded regulators," Annual Review of Microbiology, vol. 51, pp. 341-373, 1997.

[35] P.-C. Lv, H.-Q. Li, J. Sun, Y. Zhou, and H.-L. Zhu, "Synthesis and biological evaluation of pyrazole derivatives containing thiourea skeleton as anticancer agents," Bioorganic and Medicinal Chemistry, vol. 18, no. 13, pp. 4606-4614, 2010.

[36] N. K. N. A. Zawawi, M. Taha, N. Ahmat et al., "Synthesis, in vitro evaluation and molecular docking studies of biscoumarin thiourea as a new inhibitor of $\alpha$-glucosidases," Bioorganic Chemistry, vol. 63, pp. 36-44, 2015.

[37] E. Tatar, S. Karakuş, S. G. Küçükgüzel et al., "Design, synthesis, and molecular docking studies of a conjugated thiadiazole-thiourea scaffold as antituberculosis agents," Biological and Pharmaceutical Bulletin, vol. 39, no. 4, pp. 502-515, 2016.

[38] M. Meyer, P. Wilson, and D. Schomburg, "Hydrogen bonding and molecular surface shape complementarity as a basis for protein docking," Journal of Molecular Biology, vol. 264, no. 1, pp. 199-210, 1996.

[39] S. Purser, P. R. Moore, S. Swallow, and V. Gouverneur, "Fluorine in medicinal chemistry," Chemical Society Reviews, vol. 37, no. 2, pp. 320-330, 2008.

[40] Y. He, Y. Wang, L. Tang et al., "Binding of puerarin to human serum albumin: a spectroscopic analysis and molecular docking," Journal of Fluorescence, vol. 18, no. 2, pp. 433-442, 2008. 

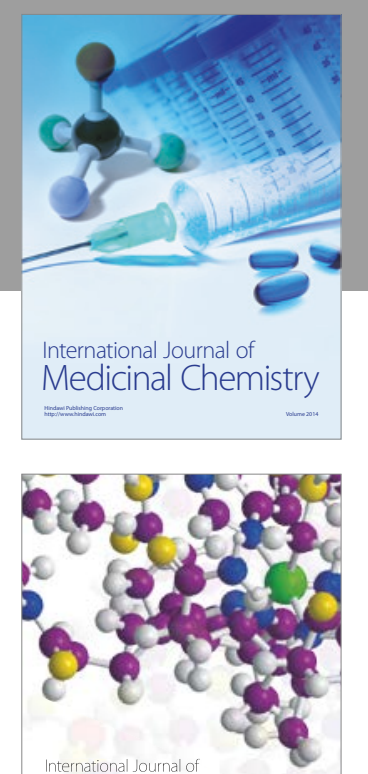

Carbohydrate Chemistry

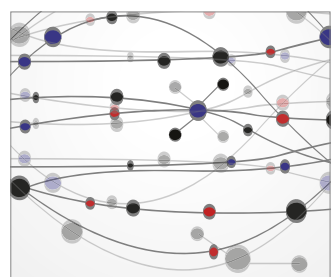

The Scientific World Journal
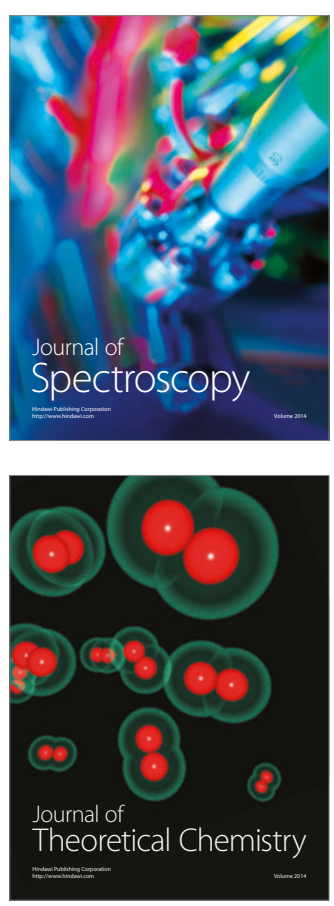
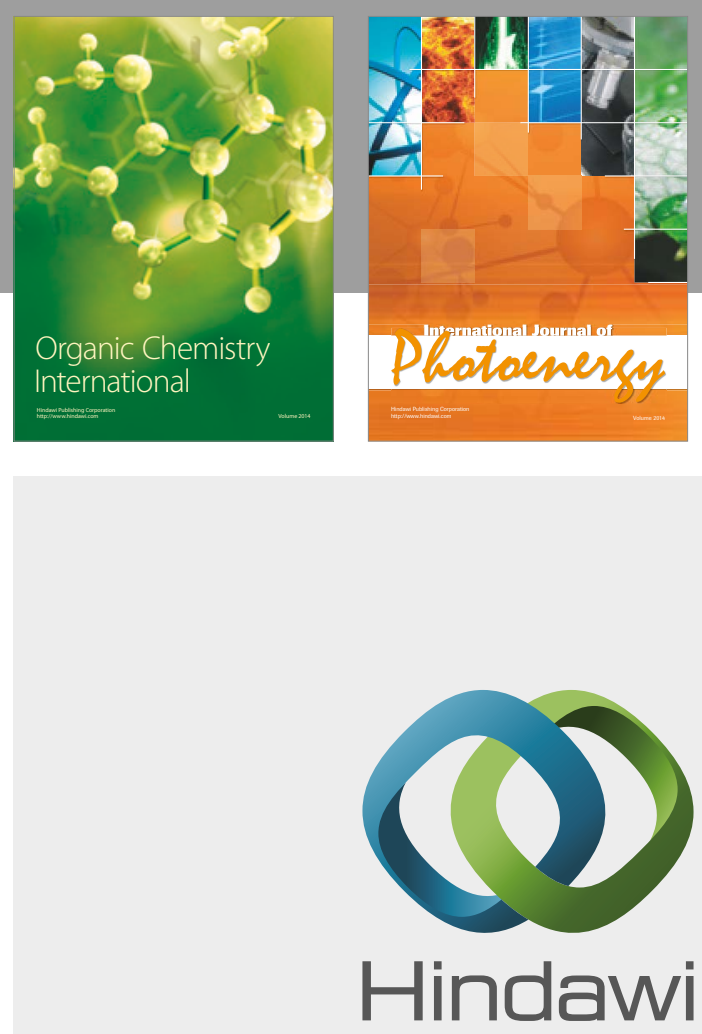

Submit your manuscripts at

https://www.hindawi.com

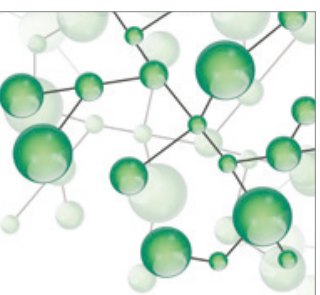

International Journal of

Inorganic Chemistry

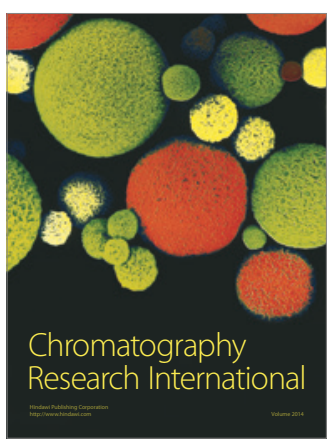

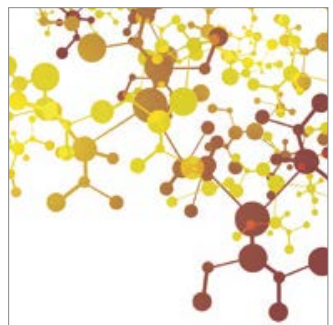

Applied Chemistry
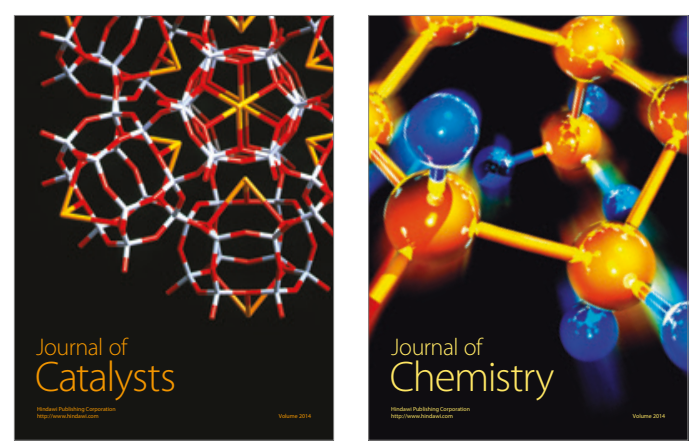
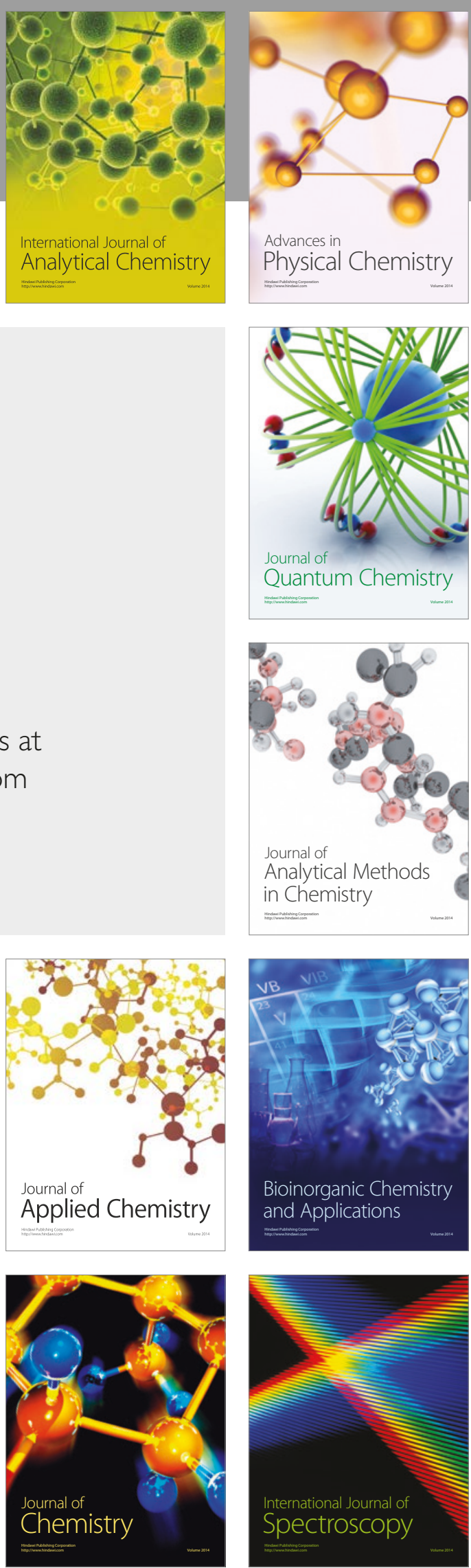